Western University

Scholarship@Western

Aboriginal Policy Research Consortium International (APRCi)

$11-2008$

\title{
On Cross-Cultural Interpretations of Aboriginal Art
}

Darren Jorgensen

Follow this and additional works at: https://ir.lib.uwo.ca/aprci

Part of the Sociology of Culture Commons

Citation of this paper:

Jorgensen, Darren, "On Cross-Cultural Interpretations of Aboriginal Art" (2008). Aboriginal Policy Research Consortium International (APRCi). 359.

https://ir.lib.uwo.ca/aprci/359 
This article was downloaded by: [University of Western Ontario]

On: 10 December 2012, At: 08:23

Publisher: Routledge

Informa Ltd Registered in England and Wales Registered Number: 1072954 Registered

office: Mortimer House, 37-41 Mortimer Street, London W1T 3J H, UK

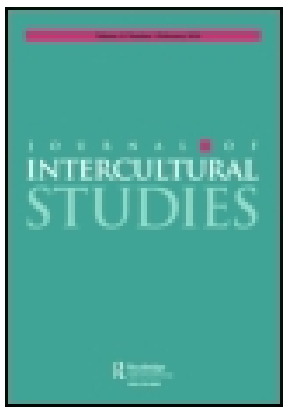

\section{J ournal of Intercultural Studies}

Publication details, including instructions for authors and subscription information:

http:/ / www. tandfonline.com/loi/ cjis20

\section{On Cross-Cultural Interpretations of Aboriginal Art}

Darren J orgensen

Version of record first published: 16 Sep 2008.

To cite this article: Darren J orgensen (2008): On Cross-Cultural Interpretations of Aboriginal Art, J ournal of Intercultural Studies, 29:4, 413-426

To link to this article: http:// dx.doi.org/ 10.1080/ 07256860802372352

\section{PLEASE SCROLL DOWN FOR ARTICLE}

Full terms and conditions of use: http://www.tandfonline.com/page/terms-andconditions

This article may be used for research, teaching, and private study purposes. Any substantial or systematic reproduction, redistribution, reselling, loan, sub-licensing, systematic supply, or distribution in any form to anyone is expressly forbidden.

The publisher does not give any warranty express or implied or make any representation that the contents will be complete or accurate or up to date. The accuracy of any instructions, formulae, and drug doses should be independently verified with primary sources. The publisher shall not be liable for any loss, actions, claims, proceedings, demand, or costs or damages whatsoever or howsoever caused arising directly or indirectly in connection with or arising out of the use of this material. 


\title{
On Cross-Cultural Interpretations of Aboriginal Art
}

\section{Darren Jorgensen}

\begin{abstract}
This paper critiques three schools of international art scholarship and their relevance to Australian Aboriginal art from remote communities. These schools are primitivism, histories of ornament and aesthetic theory. This is with a view to looking beyond accounts of Aboriginal art as representational, and toward a cross-cultural and sensual account of its practice. While primitivism influenced the scholarship on high art, histories of ornament and aesthetic theory offer new approaches to this art, and new ways of thinking about Aboriginal painting. The paper partly argues that the extensive influence of primitivism has prevented these latter areas of study in having much impact on the study of Aboriginal art, as critics attend to the inequitable relationship between indigenous and non-indigenous societies. Instead, the interest of ornament and crosscultural aesthetics in the visual rather than socio-economic and postcolonial conditions of artistic production conceives of a more equitable exchange between cultures, and a revised account of modern visual practices.
\end{abstract}

Keywords: Aboriginal Art; Cross-Cultural Aesthetics; Ornament; Primitivism

\section{Introduction}

This paper critiques three schools of international art scholarship and their relevance to Australian Aboriginal art from remote communities. These schools are primitivism, histories of ornament and aesthetic theory. This is with a view to expanding the range of criticism on Aboriginal art. Such criticism is notoriously lacking, even in Australia (Rothwell). As I will argue, the legacy of a colonialism that once silenced Aboriginal representations continues this silence surrounding Aboriginal art. Turning to ornament and aesthetic theory as ways of understanding Aboriginal art is helpful

\footnotetext{
Darren Jorgensen is a lecturer in art history in the Faculty of Architecture, Landscape and Visual Art, at the University of Western Australia. He has previously published on Aboriginal art and representations in Arena Journal, Australian Cultural History and Journal of Australian Studies. He also writes on critical theory, visual culture, science fiction and utopia. Correspondence to: Darren Jorgensen, ALVA (M433), University of Western Australia, 35 Stirling Hwy, Crawley, Western Australia 6009, Australia. Email: darren.jorgensen@uwa.edu.au
} 
for thinking beyond what Howard Morphy describes as inside and outside meanings of Aboriginal art (78-99). The inside meanings are relevant to Aboriginal communities, relating to tradition, ceremony and the country to which the art is tied. The outside meanings are representational, constructed as the art travels from its place in country to hang on the walls of urban galleries and homes. The distinction is itself generative of much of the scholarship on Aboriginal art. Anthropology, for instance, often converts the inside meaning of artefacts into an outside meaning, collecting or documenting such objects in order to account for their function. The trade in objects between anthropologists and Aboriginal people took place at the forefront of colonisation. Anthropologists collected artefacts that now make up substantial portions of significant Australian art collections. The transition that Aboriginal visual production made between anthropology and art, in the eyes of outsiders at least, has been problematic as different methodologies confront the same objects. This is why this paper begins with an account of primitivism, which is stridently critical of colonial representations of colonised cultures. The remaining two schools of thought discussed here, ornament and aesthetic theory, are, like primitivism, symptomatic of modern discourse, yet I want to argue that they also hold valuable critical insights for understanding the ways in which Aboriginal artists have manipulated and intervened in modernity.

It is, then, with a view to departing from the paradigm of colonialism in understanding the relationship between Aboriginal artists and consumers of art that I want to turn to histories of ornament and aesthetic theory as ways of thinking about this manipulation and intervention. In art history, the category of ornament occupies a paradoxical position as it is both named by and excluded from histories of high art, and yet this history is also structured by this exclusion. Historians of ornament celebrate its problematic place so as to turn ornamental styles and their influence into a more equitable version of modernity. The anonymous artisans responsible for weaving and carving become the visual innovators of modernity. Contemporary aesthetic theory is also interested in tracing common visual ideas between cultures, the senses being common to human beings. Aboriginal artists well understand the process of visual translation from one culture to another. While often lacking skills in European languages, remote Aboriginal artists have been more than articulate in visual media. Western discourses have inherited a paradigm of translation in which such images come to stand for something else, in which the planarity of art's surface is interchangeable with a writing that transfers its meaning from painted to written signs and back again. The Aboriginal difference is not one produced within a system of cultural production, but also by an absolute difference of tradition, language and culture. Art scholarship is useful for thinking through such difference, which is also an identity, as painting is invested with a lived energy that the sensorium recognises as a knowledge that is not contained by tradition, language or culture. Aboriginal art has been successful not only because it represents something else; it has also been invested with energy of art making consequent upon the local conditions of its production. 
Aboriginal art from remote communities is invested with the urgency of its total place in the world. This place is country, the regional and spiritual affiliation of the artist with traditions of land. Translating country to people from a non-Aboriginal background has been of some importance to Aboriginal people, because these colonisers have been responsible for granting rights over land. Scholarship has also been caught up in this demand for Aboriginal representations. It is instead to the ergon or sensible essence of art that we can turn to make sense not of what this art represents but of what is shared between Aboriginal artists and appreciators of this art. As the anthropologist Eric Michaels observed:

I think you can pick up a Yuendumu canvas directly from its site of production (these politically grotesque, post-colonial, depressed, third world desert camps and settlements) and drop it straight into any contemporary New York, Cologne or Paris art gallery and, without explanation, documentation or apology, it will 'work' in these settings. (28)

The mystery of this visual translation may hold keys to understanding something of the way in which difference might be negotiated between cultures, if not the mystery of art itself. Another prominent writer on Australian affairs is Marcia Langton, who tells us that the qualitative value of these paintings is shared between cultures:

I think there would be a great deal of convergence between Aboriginal views and art curators views on that matter of what constitutes, using the conventional term, 'fine art' in this context.

How such a convergence takes place is of interest here, as the spiritual power of remote country transcribes itself directly into a fine art context. This is the central problematic that scholarship on Aboriginal art confronts, one that is constructed within the disciplines of modern thought and yet which looks beyond these disciplines. I now want to turn to primitivism as symptomatic of this contradiction.

\section{Primitivism}

Primitivism is a well-established theme in art scholarship, and one grounded in the influence of African and Oceanic arts on the European avant-garde. The most recent revival in studies of primitivism was prompted by the 1984 exhibition "Primitivism" at the Museum of Modern Art in New York. Here canonical avant-garde paintings by Pablo Picasso, Henri Matisse and Paul Gaugin were exhibited next to the artefacts from Africa and Oceania that inspired them. The exhibition received intensive criticism from a postcolonial theory that was then in its heyday, which claimed that these artefacts had been appropriated from their cultural context only to bolster a Eurocentric art history. That the catalogue did not name the anonymous artists of the third and fourth world whose pieces were displayed so publicly, while glorifying the names of European artists, was symptomatic of the neglect of third and fourth world art practices by European art institutions and scholars. In such a format, 
"Primitivism" could only reinstate a patriarchal history of the avant-garde that credits Western artists with great insight into primitive aesthetics (for these criticisms, see Barkan and Bush; Harrison, Frascina and Perry; Hiller).

By the 1970s, primitivism had turned from being the study of a certain style of art, such as in Robert Goldwater's Primitivism in Modern Art, into a term with negative associations. To be a primitivist was no longer to be an innovator in contemporary art, but to exist in an uneasy relation with third and fourth world artists. A 1989 exhibition, "Magicians of the Earth" at the Centre Pompidou in Paris, would also meet a wave of criticism despite a very different methodology behind its exhibition of artists from around the world. Like "Primitivism", "Magicians of the Earth" foregrounded the relationship between art from different parts of the world. Its unifying theme was not the European avant-garde, however, but the Earth, and visual practices that relate to it. However, the exhibition once again became symbolic of problems of appropriation. Rasheed Areen, the editor of the postcolonial art journal Third Text, makes multiple criticisms of the exhibition in his introduction to a special edition on "Magicians of the Earth" ("Our Bauhaus"). For Areen the equality of the art on display erases the differences between them, and in this erasure blurs certain presumptions that the curator made when seeking art from different parts of the world. He points to the Ceremonial Ground Painting (1989) by artists from the remote Australian community of Yuendumu:

\begin{abstract}
Entering the Grand Hall of LA Villette and looking towards the end wall, one immediately noticed a large work by Richard Long which covered the whole wall and overshadowed everything else. However, on approaching it, one then saw traditional works by Esther Mahlangu (South Africa) and by the Yuendumu Aboriginal community (Australia). All these works were placed in such a way that their 'similarities' eradicated their differences. ("Our Bauhaus" 11)
\end{abstract}

This erasure of difference is of principal importance to Areen, as exhibition practices come to colonise the very cultures they are attempting to put on display. One solution to the problematic exhibition of Aboriginal art was suggested in 1989 in Third Text: Anne-Marie Willis and Tony Fry's "Art as Ethnocide" regards the whole Aboriginal art movement, then only beginning to find international recognition, as effecting an obliteration of Aboriginal cultures. The authors argue that non-Aboriginal people should silence themselves with regard to the painting, so as not to join the exploitations and appropriations of the Aboriginal art industry.

This argument for silence with regard to Aboriginal topics is endemic in the history of Australia itself, where Aboriginal people have been denied all kinds of representation. The novelty of this argument is that this silencing is in fact for the good of Aboriginal people. The historical absence of Aboriginal representation makes very few representations highly contested, the few public figures of Aboriginality in Australia come to stand for all Aboriginal people. The complex position of nonIndigenous Australians with regard to the new Aboriginal art movement may best be articulated by the reviewer of a 1986 exhibition of Papunya Tula paintings. Marco 
Marcon's review stands as something of an indication of just how insecure critics were in their ability to comment on the paintings. He writes that:

Looking at the Aboriginal works in this exhibition, I felt the necessity to question the nature of my aesthetic response to them. I was suspicious of the pleasure they aroused [...] I needed, quite clearly, a framework of values in which to locate the paintings. (38)

The absence of such a framework is testament to the absence of Aboriginality in Australian culture. Critics were unable to articulate an effective response to the new art movement because their reaction to the art was immersed in the complexities of Aboriginal representation in Australia.

More recently the critical interests of postcolonialism have changed. The founder and editor of Third Text, Rasheed Areen, voiced his dissatisfaction with postcolonialism and went so far as to call it a failure in his editorial ("A New Beginning"). Areen describes the 'Tyranny of Postcolonial Cultural Theory' in the field of art, a tyranny that while attempting to open up the art world to disenfranchised artists, simultaneously silenced their effective representation. Recent articles in Third Text have attempted to rectify this situation, arguing instead for the place of such artists in Western art history. The transformation of this critical scene also took place in the scholarship of primitivism. Marianna Torgovnick is the author of one of the most scathing studies of primitivism in European art, Gone Primitive: Savage Intellects, Modern Lives. Yet her later book, Primitive Passions: Men, Women, and the Quest for Ecstasy, changes focus to argue that these primitivisms were symptomatic of a desire for oceanic feeling, not so much for a power over the other as a merging into it. Primitivism remains a complex condition, a term of critique and description. French President Jacques Chirac wanted to distance the new Musée de Branly from it in his speech to open the space:

Central to our idea is the rejection of ethnocentrism and of the indefensible and unacceptable pretension of the West that it alone bears the destiny of humanity, and the rejection of false evolutionism, which purports that some peoples remain immutably at an earlier stage of human evolution, and that their cultures, termed 'primitive', only have value as objects of study for anthropologists or, at best, as sources of inspiration for Western artists.

The legacy of the critiques made of the Museum of Modern Art exhibition still loom large. Yet, as Natasha Ruiz-Gómez has so convincingly pointed out, the very design of this museum that features only third and fourth world artists, resurrects those primitivist motifs so thoroughly deconstructed by a previous generation of critics. She cites the architect's own words, describing his building as "a 'primitive' shelter surrounded by a 'sacred wood"' (417). So it is that primitivism remains a relevant methodology for pointing out the contradictions at work in such institutions as the Musée de Branly, contradictions that lie in the consideration of art from nonEuropean backgrounds as especially different from other art. The content of this art, 
its internal meaning to the artist and community, is held to have meaning of a different order to the internal meanings of non-Aboriginal art.

\section{The History of Ornament}

A second area of scholarship that may yet prove constructive for an understanding of Aboriginal art, and which is also founded on modern categories of inclusion and exclusion, is the art historical study of ornament. These studies can themselves be divided into two categories, both of which may prove useful for an understanding of Aboriginal art from remote communities, and more particularly of its reception. The first kind of studies that are relevant here are cross-cultural studies of ornament and decoration; tracing the way in which European styles have been influenced by the trade that this continent maintained with the East. The influential guide to European design first published in 1856, Owen Jones' The Grammar of Ornament, is a famous result of studying other cultures and their visual forms. It collects motifs from around the world into a handbook for design. The second area of study traces the way in which decorative techniques made their way into modern painting. Such histories are often framed, like primitivism, in terms of their own marginalisation from histories of Western art and aesthetics (Connelly; Masheck; Snodin and Howard; Trilling Language of Ornament; Ornament). So it is that these studies of ornament demonstrate the instability of such categories, as visual forms cross between contexts. Joseph Masheck's “The Carpet Paradigm: Critical Prolegomena to a Theory of Flatness", for instance, argues that the increasing planarity of painting in the late nineteenth century was due to the influence of the Arabesque, which had by then found its way from Turkish carpets and Iranian silks into popular European guides to making decorative arts. Masheck notes that terms used to criticise these emergent planar effects in the late nineteenth century came later to be used positively in descriptions of modern art. The reception of Aboriginal art has been determined by a similarly ambiguous place amidst the epistemologies of modernity. Aboriginal artists have troubled modern categories.

The second kind of study, that traces the transport of ornamental artefacts and designs back and forth from Europe, has most recently been undertaken by James Trilling. In The Language of Ornament and Ornament: A Modern Perspective, these trade routes are used to classify designs in terms of aesthetic motifs and ages, rather than according to their cultural significance. The theoretical underpinnings of such a study, which presumes that the impulse to the decorative is universal to human cultures, can be found as far back as Wilhelm Worringer's Abstraction and Empathy. Living amidst an increasingly abstract turn of the century modernism, Worringer argued that the impulse to an abstract ornament had more artistic volition, was closer to the drive to make art, than that of mimesis (55). Here the construction of ornament is a kind of primitivism, to be found in certain kinds of society, but by the time of Worringer's Form in Gothic the impulse to ornament had acquired the status of a certain spiritual aspiration. This is a historical study constructed around the idea 
of an ornamental line invested with this will to form, tracing a visual continuity between a Northern European decorative line and the Gothic style. The extension of the line from ornament to high style is of much interest to Worringer, as a reflection not of formal or aesthetic developments but spiritual aspirations.

Worringer thinks that an impulse to abstraction takes place so as to order a universe that remains mysterious to humankind. The origins of abstraction of painting from remote communities is more obscure than this, relating as it does to both ancestral spiritual designs and the stylistic history of painting in individual communities. It is possible still to read the abstractions of remote artists as an ordering of the chaotic country around them, though in many other senses this country is intricately ordered already by delicate ecosystems and regimes of hunting, burning and gathering. More relevant here, however, is the comprehension a nonindigenous viewer has of this aesthetic, patterns conceived out of an ancient system of knowledge that nonetheless appeals to the modern eye. Aboriginal art has, like the Gothic style, made the transition from a nomadic culture to a high European one, establishing what Worringer describes as an independent life of line, and what I am here calling a cross-cultural aesthetic. While Worringer's Form in Gothic discovers such visual crossings taking place after the tenth century, in more recent times art history places the collision of culturally distinct visual forms under the rubric of modernism. In Central and Northern Australia, this collision has produced a distinctive form of modern art, designs once drawn on bodies and sand that have been radically adapted and transformed for canvas. When the designs of third and fourth world cultures had previously made their way to Europe, they were adopted for decorative or ornamental purposes. In this case, however, artists were painting on the medium most cherished by the conventions of the Western art world, the canvas. What was once regarded as ornamental, this being the aesthetics of third and fourth world peoples, comes to be central to the media of modern art. In this, the successes of Aboriginal art simulates the movement of modernism, in which the peripheral comes to occupy centre stage, as that which was excluded from high art turns into an innovative aesthetic practice.

It is with reference to this history of European art that studies of decoration locate themselves, and by which the success of Aboriginal painting might be better understood. In Susan Connelly's The Sleep of Reason: Primitivism in Modern European Art and Aesthetics we find a configuration of high modern European painting, with both the primitive and the ornamental. She traces the influence of ornament on the development of the idea of primitivism in the eighteenth and nineteenth centuries. These formative contradictions for the production of modern art may well prove insightful for the understanding of modern Aboriginal painting. For while this painting is intimately linked to the ontologies of indigenous country, the passage from these places to the walls of homes and galleries enacts a deterritorialisation of such ontologies. Internationally, the rise of the Aboriginal art movement in the 1980s coincided with the international art market's return to painting, a return that would overcome the more radical explorations of media in the 1960s and 1970s. The 
intervention of Aboriginal artists influenced this conservative turn, creating an aesthetic of historical and, as we shall see, political relevance.

Here the separation between remote and urban artists provides a convenient means by which to imagine this intervention. The recent paintings of John Citizen render highly coloured domestic interiors that are themselves decorated with what appear to be Aboriginal paintings, paintings within paintings whose desert colours are in harmony with chairs, tables and lounge suites. Citizen inherits a critical style of painting from Robert Campbell Jr., who worked when Aboriginal art was first receiving recognition. Amid national debates about the reconciliation between races, Campbell parodied the commercialism and symbolism of its designs. In Roped off at the Pictures (1987), dot patterns make up the wallpaper of a segregated cinema, with Aboriginal viewers roped into the first three rows. The viewers, focused on a cowboy movie, do not notice that the space they inhabit is Aboriginal space. Their interest is exclusively in the white world presented to them within the moving frames of the cinema. Dot painting also makes up the background of Didgeridoo Man (1982), while in the foreground of this painting are icons of Aboriginality, such as native animals and Wandjina rock art figures. The Didgeridoo man himself, like so many of Campbell's Aboriginal figures, wears a tie atop a dark body. The contradictions insipid to an Anglophonic interest in Aboriginal Australia play themselves out in such images, which parody the kinds of contradictions that the intervention of Aboriginal artists has made into Australian life.

So it is, then, that the study of the decorative has at least two potential outcomes. One has to do with an improved understanding of the way in which Aboriginal painting has been able to achieve success in the West, the way in which it has manipulated the categories of modernity to intervene into historical and domestic space. Another is more interested in the way in which this painting is able to transcend cultures, the way in which such designs are independent of their production and consumption. In this sense Aboriginal art has precedents in the trade in Turkish carpets and Iranian silk in the last century, decorative patterns making sense to different cultures, although lacking the meanings that these cultures attribute to them. Such studies in international trade are particularly relevant today as modernity turns into an all embracing globalism, and the international market for Aboriginal art is stronger than ever before. Modernism's adoption of decorative motifs from other cultures to construct its own high art is something of a precedent for the contradictions to be found in the success of Aboriginal art.

\section{Aesthetic Theory}

The third scholarship of interest here is aesthetic theory. The term encompasses a wide range of writing and subjects of analysis, its themes largely derived from European aesthetic philosophy. Until phenomenology, aesthetics was as close as philosophy got to describing experience. Its close ties to art are inherited from Immanuel Kant's Critique of Judgement, which describes mountains and landscapes 
that were also the subject of fine art in Kant's time. The fact that Kant rarely left his native town meant that he was dependent on such representations to think through a philosophy of aesthetics, and thus to think through the relationship between the mind and its sensory surrounds. This European heritage brings to contemporary aesthetics a similar set of anxieties about the modality of its thought as that of primitivism and ornament. Wanting to create a universal body of knowledge, aesthetics invariably finds itself recreating the hegemony of a discourse styled after Western content. Only recently, aesthetics has come to more explicitly include the visual practices of other cultures. The nomination of cross-cultural aesthetics as a particular field of study is an attempt to de-Europeanise the content of this philosophical heritage. From its very beginnings, aesthetics wanted to redress an increasingly rationalistic European philosophy with a science of the human senses. Cross-cultural aesthetics redresses a European visual bias, proposing that this sensorium is itself determined by culture. The generative contradiction of aesthetics, the distance between a reasoning language and the affects of the body, turns into a comparison of the reasonings of these affects. Different aesthetic systems describe new ways of thinking the conditions of embodiment and visual practice. Thus Susan M. Vogel's African Aesthetics describes resemblance, luminosity, self-composure, youthfulness and clarity of form as criteria for thinking of African figures.

Such culturally specific studies are supplemented by accounts of the influences and counter-influences of aesthetic traditions. Here there has been much work on the traffic between Europe and the Far East. In China and Japan artists did not always labour anonymously, the names of great court artists lending themselves to the historiographic strategies of art history (Lambourne; Mody; Mungello; Sullivan). It is on the basis of these extensive traditions of documentation in China and Japan that cross-cultural aesthetic theory has been able to institutionalise itself. The "East and West in Aesthetics" series, organised by Grazio Marchiano in the late 1970s and 1980s is exemplary here. Other studies offer comparisons between the appreciation of a visual motif in more than one culture. Rudolf Wittkower's work is a powerful example: his Allegory and the Migration of Symbols is interested in the way in which symbols, such as the eagle and serpent, have travelled between cultures and has been adopted symbolically by them. Wittkower comes from an art historical tradition that has had some experience in tracing the survival of symbols from one situation to another. Largely, however, such work in art history has been conducted with a view to tracing images that have passed from one historical period of European art to another (Warburg; Panofsky), surely a less surprising occurrence than the passage of visual ideas from one completely different people to another.

These different kinds of cross-cultural study: of different and differential aesthetic systems; of artists and art practices influenced by another visual culture; and of the passage of visual motifs from one culture to another; reproduce themselves in accounts of contemporary Aboriginal art. The study of fourth world art practices in the context of their traditions has more often been left to anthropologists, whose interest and expertise in first nations worldwide has afforded them a privileged place 
with regard to such knowledge. Nelson H. H. Graburn's 1976 volume, Ethnic and Tourist Arts, for instance, is a collection of articles about all kinds of fourth world cultural expressions, from African ebony carving to the dyed yarns of Peruvian tribes. The volume's 20 essays are largely by anthropologists, with only two art historians among them (Abramson; Brody). Studies of the way in which artists, artefacts and art practices are constituted at the border of different cultures are more common now, as developments in anthropology and art history confront their Eurocentric bias. Material Culture Studies, for example, has been a guiding methodology for anthropologists and theorists attempting to understand Aboriginal arts (Massumi; Morphy and Perkins; Myers). Studies of the ways in which artefacts travel between cultures are not only useful in outlining different aesthetic systems, but also in reflecting upon the limited frameworks by which culture is itself understood. Morphy's distinction between the inside and outside meanings of Aboriginal art is one example of how Material Culture Studies can trace such limits. His Ancestral Connections describes the way in which the raark style of North-Eastern Arnhem Land has different meanings for Yolngu people and non-Yolngu people.

Another field of research are artists who cross between Indigenous and Western cultures, to create hybrid visualities with elements of both. Campbell is an example of such an artist. Such research may well include collaborations between painters from remote communities and other artists. It may include a history of Australian artists influenced by Aboriginal aesthetics, such as Margaret Preston, whose paintings of Australian flora were heavily influenced by her conception of Aboriginal colour and figure. In Australia a later generation of non-Indigenous artists were compelled to travel to remote communities and work there, before returning to the urban centres having lived amidst the art boom of Central and Northern Australia. Erica Izett reports that such artists "learnt not so much a style of painting but a way of making art that, no matter how individual, is notably informed by an Indigenous ethic of place" (26). Other artists are directly indebted to the style of painting from remote communities. After living in Central Australia for a time, painter Tim Johnston returned to Sydney to paint Buddhist and Hindu icons floating in skyscapes dotted in the Aboriginal style. The spiritual figures of the East, appropriated by the Western counter-culture, are themselves appropriated here within an appropriation of the dotting technique. Such images reveal something of the way in which Australian Aboriginality has found a place in the eclectic imagination of spirituality in Western culture. One of the advantages of researching artists who have been immersed in one culture or another is that they are able to articulate, visually and sometimes discursively, elements of aesthetic transcoding between them.

Here the abstraction of painting from remote communities may well betray a greater understanding between visual forms and the historical conditions of their appearance. Again, the modernity of the Aboriginal artists is comparable to other modern art practices. The displacement experienced by artists on remote communities confronted by colonial practices is the historical condition of this modernity, their abstract consequent upon it. The development of Aboriginal styles such as 
dotting and cross-hatching may well be compared with the history of abstract styles in Anglo-American art, themselves historically located. Such a history would precede the twentieth century, as the influence of foreign objects on the art of modern Europe, on early painting styles, is compared to the influence of Western objects and visualities on remote communities. While studies of the impact of foreign artefacts on Western aesthetics have been comprehensive, an examination of the impact of Western artefacts on Aboriginal artists has not yet been undertaken. This may be because Aboriginal artists have had to struggle against claims that it is influenced by external, Western influences at the price of its cultural integrity. The demands of cultural representation have again limited the potential for critical work in this area. Still, the quantity of anecdotal material on the early years of Aboriginal art (Bardon; Lendon; Michaels; Myers; Perkins; Perkins and Fink) would provide some basis for the beginnings of such a study. The cross-cultural development of visual form in indigenous communities has some international precedents, particularly in the study of souvenirs (Phillips; Phillips and Steiner; Thomas), but remains unstudied in the history of the art movements across Central and Northern Australia. Constructing a cross-cultural model for the development of the Aboriginal style would help to free the concept of abstraction from an Anglo-American notion of modernism, and to unravel the construction of an authentic or traditionalist Aboriginality.

At present, it would still be fair to say that the mainstream of global art history and art theory in English is constituted with reference to Anglo-American artists and Anglo-American art. Outside Australia, the painting movement from remote Australian communities is commonly seen as ethnic or naive, traits that do not distinguish it from other non-Western art (Greer). Cross-cultural studies of arts from different cultures aim to redress this centralisation of art history; by privileging the multiplicity of global art movements in order to destabilise the standards by which these discourses understand themselves. Cross-cultural aesthetic theory effects a reassessment of the European and American tradition of contemporary art by establishing fourth world artists as formal innovators in the field of modernism. To privilege Indigenous artists in cross-cultural studies is to argue that they offer unique insights into the development of visual culture that are not available to scholars working with European and American content, however marginal this content may be. Cross-cultural aesthetic theory works within a revisionist tradition of art history and art theory, by privileging new and non-canonical objects for study.

\section{Conclusion}

While primitivism attends to the structural and representational conditions of the disempowerment of fourth world artists, the focus of cross-cultural studies of ornament and aesthetic theory are elsewhere. They create continuities out of art and artefacts from many ages and many peoples, and aim to create an equitable situation for visual producers amidst the discriminations of modernity. It is part of the contradiction of these studies that they are themselves consequent upon such 
discriminations, and that their arguments are founded in European discourses. Yet their interest in anonymous artists and varied visual practices signal important revisions to understanding the visual innovations of modernity, and suggest that modernity is a phenomenon that is not exclusively derived from European practices. Studies of ornament and cross-cultural aesthetics point out to what degree visual ideas have their origins in the cultural collision between different peoples. While primitivism emphasises the heritage of inequitable relations between the West and its colonies, these fields of study do not necessarily regard these relationships as inequitable. These latter studies may well be placed alongside revisionist histories of the colonial period, in which the agency of third and fourth world peoples is better represented. Cross-cultural studies in particular have the potential to take into account the agency of fourth world artists, such as Aboriginal artists, who are working in traditions established before the colonial period.

A central problem in discourses on Aboriginal art is that this art is taken to be representative of Aboriginal people, their traditions, culture and situation. The art scholarships described above are also interested in methodologies that do not emphasise such processes of translation from image to language. They attempt to think the stylistic and sensual aspects of visual communication. When Aboriginal art stands in for Aboriginality it can have the effect of reducing the dimensionality of such sensual, aesthetic meanings. The irony here is that this painting is also very political. This, not in the representational sense of the term, but in the sense of a struggle for representation. Amidst a changing political situation for artists, at a time when the Federal government is pursuing new tax and welfare strategies on remote communities, and removing subsidised Aboriginal workers from art centres, it is crucial to understand the nature of this politic. Plato excluded artists from participation in his Republic because they were too busy to have time to represent their own interests. Their work was too urgent, demanded too much, to be subject to the rigours of discourse and representation (Ranciere 12). It is up to critics to represent what is unrepresentable, to reveal within this living art practice these demands for equity within a different tradition of visual production.

\section{Works Cited}

Abramson, J. A. "Style Change in an Upper Sepik Contact Situation." Ethnic and Tourist Arts: Cultural Expressions from the Fourth World. Ed. Nelson H. H. Graburn. Berkeley: University of California Press, 1976. 249-65.

Areen, Rasheed. “Our Bauhaus Others' Mudhouse.” Third Text 6 (Spring 1989): 3-14. . "A New Beginning: Beyond Postcolonial Cultural Theory and Identity Politics." Third Text Reader: On Art, Culture and Theory. London: Continuum, 2002. 333-45.

Bardon, Geoffrey. Aboriginal Art of the Western Desert. Adelaide: Rigby, 1979.

Barkan, Elazar, and Ronald Bush, eds. Prehistories of the Future: The Primitivist Project and the Culture of Modernism. Stanford: Stanford University Press, 1995.

Brody, J. J. Ethnic and Tourist Arts: Cultural Expressions from the Fourth World. Ed. Nelson H. H. Graburn. Berkeley: University of California Press, 1976. 70-84. 
Connelly, Frances S. The Sleep of Reason: Primitivism in Modern European Art and Aesthetics, 1725-1907. University Park, PA: Pennsylvania University Press, 1995.

Goldwater, Robert J. Primitivism in Modern Art. 1935. New York: Vintage, 1967.

Graburn, Nelson H. H., ed. Ethnic and Tourist Arts: Cultural Expressions from the Fourth World. Berkeley: University of California Press, 1976.

Greer, Germaine. “Can You Tell What it's Worth Yet?” The Guardian 9 November 2005.

Harrison, Charles, Frascina Francis, and Gill Perry. Primitivism, Cubism, Abstraction: The Early Twentieth Century. New Haven, CT: Yale University Press, 1993.

Hiller, Susan, ed. The Myth of Primitivism: Perspectives on Modern Art. London: Routledge, 1991.

Izett, Erica. "Sitting Down with Indigenous Artists." Artlink 25.2 (2005): 26-29.

Jones, Owen. The Grammar of Ornament. 1856. London: Dover, 1987.

Kant, Immanuel. Critique of Judgement. 1790. Trans. Werner S. Pluhar. Indianapolis: Hackett, 1987.

Lambourne, Lionel. Japonisme: Cultural Crossings between Japan and the West. London: Phiadon, 2005.

Langton, Marcia, Hetti Perkins, Geoffrey Bardon, and Fred Myers. "In Conversation with Michael Cathcart." Arts Today 18 August 2000. Transcript accessed 10 May 2007 from <http:// arts.abc.net.au/signal/feature/papunya.htm $>$.

Lendon, Nigel. "Space, Place, and Innovation in Bark Paintings of Central Arnhem Land" (Special issue: Colonizing the Country). Australian Journal of Art 12 (1995): 55-73.

Marcon, Marco. "Papunya Tula Paintings: Gallerie Dusseldorf." Review. Praxis M 12 (Autumn 1986): 38-39.

Masheck, Joseph. "The Carpet Paradigm: Critical Prolegomena to a Theory of Flatness." Arts Magazine September 1976: 82-109.

Massumi, Brian. "Sur le driot a la non-communication des differences." Ethnopsy: le Mondes Contemporains de la Guerison 4 (2002): 93-131.

Michaels, Eric. "Postmodernism, Appropriation and Western Desert Acrylics." Postmodernism: A Consideration of the Appropriation of Aboriginal Imagery. Ed. Sue Cramer. Brisbane: Institute of Modern Art, 1989.

Mody, N. H. N. A Collection of Nagasaki Colour Prints and Paintings: Showing the Influence of Chinese and European Art on that of Japan. Rutland, VT: Charles E. Tuttle, 1969.

Morphy, Howard. Ancestral Connections: Art and an Aboriginal System of Knowledge. Chicago: University of Chicago Press, 1991.

Morphy, Howard, and Morgan Perkins, eds. The Anthropology of Art: A Reflection on its History and Contemporary Practice. Oxford: Blackwell, 2005.

Mungello, D. E. The Great Encounter of China and the West, 1500-1800. 2nd ed. Lanham, MD: Rowman and Littlefield, 2005. 27-32, 46-55.

Myers, Fred, ed. The Empire of Things. Santa Fe: School of American Research Press, 2001.

Panofsky, Erwin. Studies in Iconology: Humanistic Themes in the Art of the Renaissance. New York: Harper and Row, 1972.

Perkins, Hetti, ed. Crossing Country: The Alchemy of Western Arnhem Land Art. Sydney: AGNSW, 2004.

Perkins, Hetti, and Hannah Fink, eds. Papunya Tula: Genesis and Genius. Sydney: AGNSW in assoc. with Papunya Tula Artists, 2000.

Phillips, Ruth. Trading Identities: The Souvenir in Native North American Art from the Northeast, 1700-1900. Seattle: University of Washington Press and Montreal: McGill-Queen's, 1998.

Phillips, Ruth B., and Christopher B. Steiner. Unpacking Culture: Art and Commodity in Colonial and Postcolonial Worlds. Berkeley: University of California Press, 1999.

Ranciere, Jacques. The Politics of Aesthetics: The Distribution of the Sensible. Trans. Gabriel Rockhill. London: Continuum, 2004.

Rothwell, Nicolas. "Crossing the Divide." The Weekend Australian 3 April 2004: B18. 
Ruiz-Gómez, Natasha. "The (Jean) Nouvel Other: Primitivism and the Musée du Quai Branly." Modern and Contemporary France 14.4 (2006): 417-32.

Snodin, Michael, and Maurice Howard. Ornament: A Social History since 1450. New Haven, CT: Thames and Hudson, 1996.

Sullivan, Michael. The Meeting of Eastern and Western Art from the Sixteenth Century to the Present Day. London: Thames and Hudson, 1973.

Thomas, Nicholas. Entangled Objects: Exchange, Material Culture, and Colonialism in the Pacific. Cambridge, MA: Harvard University Press, 1991.

Torgovnick, Marianna. Gone Primitive: Savage Intellects, Modern Lives. Chicago: University of Chicago Press, 1990.

. Primitive Passions: Men, Women, and the Quest for Ecstasy. New York: Alfred A. Knopf, 1997.

Trilling, James. The Language of Ornament. London: Thames and Hudson, 2001.

- Ornament: A Modern Perspective. Seattle: University of Washington Press, 2003.

Vogel, Susan M. African Aesthetics. New York: Center for African Art, 1986.

Warburg, Aby. The Renewal of Pagan Antiquity: Contributions to the Cultural History of the European Renaissance. Trans. David Britt. Los Angeles: Getty Research Institute for the History of Art and the Humanities, 1999.

Willis, Anne-Marie, and Tony Fry. "Art as Ethnocide: The Case of Australia." Third Text 5 (1988-89): 3-20.

Wittkower, Rudolf. Allegory and the Migration of Symbols. London: Thames and Hudson, 1977.

Worringer, Wilhelm. Abstraction and Empathy. Trans. Michael Bullock. London: Routledge and Kegan Paul, 1953.

—. Form in Gothic. Trans. Herbert Read. London: Alec Tirnati, 1957. 